\title{
In vivo multi-modal imaging of experimental autoimmune uveoretinitis in transgenic reporter mice reveals the dynamic nature of inflammatory changes during disease progression
}

Xiangting Chen ${ }^{1}$, Jelena M Kezic ${ }^{1}$, John V Forrester ${ }^{2,3,4}$, Gabrielle L Goldberg ${ }^{5}$, lan P Wicks ${ }^{5}$, Claude C Bernard ${ }^{6}$ and Paul G McMenamin ${ }^{1^{*}}$

\begin{abstract}
Background: Experimental autoimmune uveoretinitis (EAU) is a widely used experimental animal model of human endogenous posterior uveoretinitis. In the present study, we performed in vivo imaging of the retina in transgenic reporter mice to investigate dynamic changes in exogenous inflammatory cells and endogenous immune cells during the disease process.

Methods: Transgenic mice (C57B//6 J CX $\mathrm{Cr}_{3} \mathrm{GFP}^{\mathrm{G} /+}$, C57BI/6 N CD11C-eYFP, and C57B//6 J LysM-eGFP) were used to visualize the dynamic changes of myeloid-derived cells, putative dendritic cells and neutrophils during EAU.

Transgenic mice were monitored with multi-modal fundus imaging camera over five time points following disease induction with the retinal auto-antigen, interphotoreceptor retinoid binding protein (IRBP $\left.{ }_{1-20}\right)$. Disease severity was quantified with both clinical and histopathological grading.

Results: In the normal C57B//6 J $\mathrm{CX}_{3} \mathrm{Cr}^{\mathrm{GFP} /+}$ mouse $\mathrm{CX}_{3} \mathrm{Cr} 1$-expressing microglia were evenly distributed in the retina. In C57BI/6 N CD11C-eYFP mice clusters of CD11c-expressing cells were noted in the retina and in C57BI/6 J LysM-eGFP mice very low numbers of LysM-expressing neutrophils were observed in the fundus. Following immunization with IRBP $_{1-20}$, fundus examination revealed accumulations of $\mathrm{Cx}_{3} \mathrm{Cr}_{1-\mathrm{GFP}^{+}}$myeloid cells, CD11c-eYFP ${ }^{+}$cells and LysM-eGFP ${ }^{+}$ myelomonocytic cells around the optic nerve head and along retinal vessels as early as day 14 post-immunization. CD11c-eYFP ${ }^{+}$cells appear to resolve marginally earlier (day 21 post-immunization) than C $x_{3}$ Cr1-GFP $^{+}$and LysM-eGFP ${ }^{+}$ cells. The clinical grading of EAU in transgenic mice correlated closely with histopathological grading.

Conclusions: These results illustrate that in vivo fundus imaging of transgenic reporter mice allows direct visualization of various exogenously and endogenously derived leukocyte types during EAU progression. This approach acts as a valuable adjunct to other methods of studying the clinical course of EAU.
\end{abstract}

Keywords: Experimental autoimmune uveoretinitis, Reporter mice, Clinical imaging, Retinal inflammation, Microglia, Neutrophils, Dendritic cells

\footnotetext{
* Correspondence: paul.mcmenamin@monash.edu

'Department of Anatomy and Developmental Biology, School of Biomedical

Sciences, Faculty of Medicine, Nursing and Health Sciences, Monash

University, Clayton, Victoria, Australia

Full list of author information is available at the end of the article
} 


\section{Introduction}

Uveitis is the fourth leading cause of blindness in the working age population in developed countries [1,2]. Endogenous posterior uveoretinitis makes up 22\% of uveitis cases [3]. The aetiology of non-infectious uveoretinitis is unknown in most cases and has been considered to have an autoimmune basis $[4,5]$. Well-established animal models of experimental autoimmune uveoretinitis have provided a valuable experimental platform for improving our understanding of the disease pathogenesis and mechanisms of autoimmune uveoretinitis [4-8].

Experimental autoimmune uveoretinitis (EAU) is an organ-specific, T-cell mediated disease that can be induced in susceptible mouse strains by direct immunization with retinal antigens, including interphotoreceptor retinoid binding protein (IRBP) or arrestin (retinal soluble antigen, $\mathrm{S}$-antigen), in complete Freund's adjuvant and a simultaneous intraperitoneal injection of pertussis toxin. Alternatively, EAU can be induced indirectly by adoptive transfer of retinal antigen-specific effector $\mathrm{T}$ cells [4]. Disease usually develops around 10 to 14 days after immunization and is clinically evident within the retina as inflammatory cell infiltration which will include macrophages [9], dendritic cells (DCs) [10], neutrophils [11] and $\mathrm{T}$ cells $[9,11]$. In addition to the influx of blood-derived leukocytes, the resident myeloid-derived macrophages, retinal microglia, are also activated during EAU $[7,8]$.

The $\mathrm{Cx}_{3} \mathrm{Cr}^{\mathrm{gfp} /+}$ transgenic knock-in mouse [12] has enabled exquisite in vivo and ex vivo visualization of the dynamic changes in microglia in steady and diseased states in the eye [13-17], as well as in the brain [18,19], and in particular their rapid responsiveness to injury and presence of noxious stimuli $[14,15]$. The study of $\mathrm{Cx}_{3} \mathrm{cr}$ 1-bearing brain microglia in vivo in these reporter mice requires the surgical creation of a defect or window in the calvaria and two-photon microscopic examination of the superficial cortex [20]. By contrast, the eye offers unique advantages for direct in vivo visualization of infiltrating and resident immune cells in reporter mice with minimal experimental manipulation [16,21-23]. However, to date there has been limited use of reporter mice to investigate the dynamics of infiltrating leukocytes and resident myeloid cells in an ocular model of autoimmunity.

In the present study, we demonstrate that in vivo fundus examination of transgenic reporter mice facilitates monitoring of the dynamic changes in various exogenously and endogenously derived cells of myeloid lineage during EAU progression. In particular we chose to examine EAU in transgenic mice $\left(\mathrm{C} 57 \mathrm{Bl} / 6 \mathrm{~J} \mathrm{Cx} x_{3} \mathrm{Cr} 1^{\mathrm{GFP} /+}, \mathrm{C} 57 \mathrm{Bl} / 6 \mathrm{CD} 11 \mathrm{c}\right.$ $e Y F P$, and $C 57 B l / 6 \mathrm{~J}$ LysM-eGFP) in which promoter elements of the myeloid-specific $C x_{3} c r 1, C D 11 c$ and lysM genes are expressed alongside a specific fluorescent reporter in an attempt to characterize the relative temporal pattern of resident and infiltrating myeloid cells, DCs, and neutrophils, respectively. Whilst we appreciate that none of these transgenic reporter mice provide definitive identification of any of the above myeloid cell subsets and thus have their limitations [24], our results do provide novel insights into the cell mediated immune events in this model of human endogenous posterior uveoretinitis and allow accurate clinical grading of disease severity that correlates with histopathological changes.

\section{Materials and methods \\ Mice}

Transgenic reporter mice in which the myeloid-specific promoter of the $C x_{3} c r 1, C D 11 c$, and lys $M$ genes drives the expression of fluorescent reporters $\left(\mathrm{C} 57 \mathrm{Bl} / 6 \mathrm{JC} \mathrm{Cx}_{3} \mathrm{Cr} 1^{\mathrm{GFP} /+}\right.$, C57Bl/6 N CD11c-eYFP, and C57Bl/6 J LysM-eGFP mice, respectively) were used in this study at an age of between 8 and 10 weeks. The details of the myeloid promoter and reporter mice used in this study are summarized in Table 1. $\mathrm{C} 57 \mathrm{Bl} / 6 \mathrm{~J} \mathrm{Cx}_{3} \mathrm{Cr} 1^{\mathrm{GFP} /+}$ mice were created by crossing homozygous $C 57 B l / 6 J C x_{3} C r 1^{G F P / G F P}$ mice, originally obtained from Professor Steffen Jung [12], to wild-type

Table 1 Transgenic reporter mouse lines

\begin{tabular}{|c|c|c|c|}
\hline $\begin{array}{l}\text { Transgenic reporter } \\
\text { mouse line }\end{array}$ & Description & Specificity & Research use \\
\hline $\mathrm{C} 57 \mathrm{Bl} / 6 \mathrm{~J} \mathrm{CX}_{3} \mathrm{Cr}^{g f p /+}$ & $\begin{array}{l}\text { Knock-in mouse line where one } \\
\text { copy of the } \mathrm{Cx}_{3} \mathrm{Cr} 1 \text { gene is replaced } \\
\text { by the GFP reporter gene [12]. }\end{array}$ & $\begin{array}{l}\mathrm{Cx}_{3} \mathrm{Cr} 1\left(\mathrm{GFP}{ }^{\mathrm{hi}}\right) \text { is expressed in } \\
\text { monocytes, subsets of natural killer } \\
\text { and } \mathrm{T} \text { cells, DCs, and microglia. }\end{array}$ & $\begin{array}{l}\text { Extensively used to study monocytes } \\
\text { during normal and diseased state in } \\
\text { gut }[72,73] \text {, kidney }[74,75] \text {, brain }[76,77] \text {, } \\
\text { and the retina of the eye }[8,78] \text {. }\end{array}$ \\
\hline C57BI/6 N CD11c-eYFP & $\begin{array}{l}\text { Reporter mouse line that } \\
\text { expresses eYFP under the } \\
\text { CD11c (Itgax) promoter [25]. }\end{array}$ & $\begin{array}{l}\text { CD11c is a cell surface molecule expressed } \\
\text { on myeloid cells, lymphocytes, natural killer } \\
\text { cells and DCs [79]. In C57Bl/6 N CD11c-eYFP } \\
\text { mice, DCs are characterized by CD11c-eYFPi } \\
\text { while B and T cells are CD11c-eYFP }{ }^{\text {lo }} \text { [25]. }\end{array}$ & $\begin{array}{l}\text { Extensively used to study distribution } \\
\text { of DCs in numerous organs including } \\
\text { the brain [31,32,80], lung [34], skin [35], } \\
\text { gut [36], and the cornea of the eye [33]. }\end{array}$ \\
\hline C57BI/6 J LysM-eGFP & $\begin{array}{l}\text { Reporter mouse line that } \\
\text { expresses eGFP under the } \\
\text { LysM promoter [26]. }\end{array}$ & $\begin{array}{l}\text { LysM is expressed in neutrophil } \\
\text { granulocytes (LysM-eGFPhi }) \text { and } \\
\text { macrophages (LysM-eGFPlo })[26,37] \text {. }\end{array}$ & $\begin{array}{l}\text { Widely used to study neutrophil } \\
\text { extravasation during infection }[81,82] \\
\text { and inflammation }[37,83] \text {. }\end{array}$ \\
\hline
\end{tabular}

DC, dendritic cell; GFP, green fluorescent protein; eGFP, enhanced green fluorescent protein; eYFP, enhanced yellow fluorescent protein; LysM, Lysozyme M. 
C57Bl/6 J mice. C57Bl/6 N CD11c-eYFP mice express enhanced yellow fluorescent protein (eYFP) under the promoter for the Itgax (CD11c) gene and are widely regarded as a valuable model for investigating the distribution of DCs with the caveat that other cells are capable of limited expression of CD11c [25]. C57Bl/6 N CD11c-eYFP breeding pairs were kindly provided by Associate Professor Michael Hickey (Monash University, Clayton, VIC, Australia) with permission from Professor Michel Nussenzweig (The Rockefeller University, New York, NY, USA) from whom the original mice were obtained [25]. C57Bl/6 J Cx $x_{3} C r 1^{G F P /+}$ and C57Bl/6 CD11ceYFP mice were bred at the Monash Large Animal Facility (Monash University). C57Bl/6 J LysM-eGFP mice were kindly provided by Associate Professor Michael Hickey. C57Bl/6 J LysM-eGFP mice were created by cloning enhanced green fluorescent protein (eGFP) into the lysozyme $M$ (LysM) locus where LysM is expressed in myelomonoytic cells (macrophages and neutrophil granulocytes) [26]. C57Bl/6 J CX $\mathrm{Cr}_{3} \mathrm{CPFP}^{\mathrm{GFP}}$ and C57Bl/6 J LysM-eGFP mice were screened by PCR [22] and determined to be negative for retinal degeneration $8(\mathrm{rd} / 8)$ mutation in the crumbs 1 (Crb1) gene (data not shown). C57Bl/6 N CD11c-eYFP mice were found to carry the $r d 8$ mutation and this has been described in detail elsewhere [22]. All experimental animals were maintained under 12:12-hour light/dark cycle with ad libitum access to food and water. All procedures in this study were approved by the Monash Animal Ethics Committee (MARP/2011/094) and were performed in accordance with the ARVO Statement for the Use of Animals in Ophthalmic and Vision Research.

\section{Induction of experimental autoimmune uveoretinitis}

EAU was induced using a standard protocol, previously described by others [8]. Briefly mice received a subcutaneous (s.c.) injection of a total of $100 \mu \mathrm{l}$ emulsion, containing a 50:50 mix of $400 \mu \mathrm{g}$ human IRBP peptide 1-20 (IRBP ${ }_{1-20}$; GPTHLFQPSLVLDMAKVLLD; China Peptides, Shanghai, China) in complete Freund's adjuvant (CFA; Sigma-Aldrich, St Louis, MO, USA) supplemented with Mycobacterium tuberculosis H37RA $(2.5 \mathrm{mg} / \mathrm{ml}$; BD PharMingen, San Diego, CA, USA), distributed between the base of the tail and the right flank of each mouse. Mice simultaneously received an intraperitoneal (i.p.) injection of $1.5 \mu \mathrm{g}$ pertussis toxin (Sigma-Aldrich) in phosphatebuffered saline (PBS). Control mice received s.c. injection of a total of $100 \mu \mathrm{l}$ emulsion containing 50:50 mixture of CFA and PBS (no IRBP) and i.p. injection of pertussis toxin.

\section{Clinical examination of eyes}

Mice were clinically examined on day (d) 0, 14, 21, 28 and 35 post-immunization (p.i.). Mice were anesthetized by an i.p. injection of a mixture of ketamine $(80 \mathrm{mg} / \mathrm{kg}$; Troy
Laboratories, Glendenning, NSW, Australia) and xylazine (10 mg/kg; Troy Laboratories). The pupils were dilated with $0.5 \%$ tropicamide (Mydriacil, Alcon Laboratories, Vilvoorde, Belgium), and the cornea was kept moist with the application of sterile lubricant GenTeal gel (Novartis, North Ryde, NSW, Australia). The fundus was examined using the Micron III camera (Phoenix Research Laboratories, Pleasanton, CA, USA) with StreamPix 5 software. Examination consisted firstly of capturing short 5 seconds videos with 100 frames in brightfield, followed by a sequence of $\mathrm{GFP}^{+}$or $\mathrm{YFP}^{+}$cells using the green fluorescent barrier filters, and lastly by a short sequence following a $20 \mu \mathrm{l}$ s.c. injection of $10 \%$ fluorescein isothiocyanate (Alcon Laboratories, Frenchs Forest, NSW, Australia) to visualize the retinal vasculature. The brightness and contrast of all fundus images were adjusted equally using ImageJ $1.48 \mathrm{C}$ software [27].

\section{Clinical assessment of experimental autoimmune uveoretinitis}

The severity of disease was graded based on examination of the three modes of clinical fundus images (brightfield, fluorescent, and fluorescein angiography) by two masked observers using a modification of a previously described clinical grading scheme for EAU [6]. The modifications to the grading criteria (Table 2 ) were primarily a consequence of having both traditional brightfield fundus views augmented by the fluorescent capability offered by the Micron III camera.

\section{Histological assessment of experimental autoimmune uveoretinitis}

Mice were euthanized on d35 p.i. with an i.p. injection of sodium pentabarbitone (Lethabarb; Virbac, Milperra, NSW, Australia) and were perfused with $1 \%$ heparin in PBS followed by $4 \%$ paraformaldehyde (PFA) in PBS. Eyes were enucleated and stored in $4 \% \mathrm{PFA}$ at $4^{\circ} \mathrm{C}$. The right eye from each animal was post-fixed with Karnovsky fixative (4\% PFA: 1\% glutaraldehyde) for 48 hours and processed for resin histology. Tissues were embedded in Technovit glycol methacrylate resin (Heraeus Kulzer, Wehrheim, Germany), sectioned at $5 \mu \mathrm{m}$ thickness through the optic nerve-pupillary axis and stained with haematoxylin and eosin. Sections from three different levels of each eye separated by a minimum distance of $50 \mu \mathrm{m}$ were examined by light microscopy and disease severity was scored by a masked observer using the previously published histopathology grading system for mouse EAU [28].

\section{Results}

Imaging of experimental autoimmune uveoretinitis disease progression in $\mathrm{C} 57 \mathrm{BI} / 6 \mathrm{~J} \mathrm{CX}_{3} \mathrm{Cr} 1^{\mathrm{GFP} /+}$ mice In vivo clinical examination of eyes in C57Bl/6 J CX $x_{3} \mathrm{Cr} 1^{\mathrm{GFP} /+}$ mice prior to immunization revealed a normal fundus using 
Table 2 Experimental autoimmune uveoretinitis clinical grading criteria

\begin{tabular}{|c|c|c|c|c|c|c|c|c|}
\hline Score & $\begin{array}{l}\text { Retinal tissue } \\
\text { infiltrate }\end{array}$ & Optic disc & $\begin{array}{l}\text { Retinal } \\
\text { atrophy }\end{array}$ & $\begin{array}{l}\text { Retinal } \\
\text { detachment }\end{array}$ & Vasculitis & Haemorrhages & $\begin{array}{l}\text { Fluorescein } \\
\text { leakage }\end{array}$ & Vitreous haze \\
\hline 0 & $<5$ small lesions & No inflammation & Absent & Absent & Absent & Absent & Absent & $\begin{array}{l}\text { Fundus details } \\
\text { clearly visible }\end{array}$ \\
\hline 1 & $\begin{array}{l}>5 \text { small } \\
\text { linear lesions }\end{array}$ & Minimal inflammation & Absent & Absent & Minimal thickening & Absent & Mild & $\begin{array}{l}\text { Fundus details } \\
\text { clearly visible }\end{array}$ \\
\hline 2 & $\begin{array}{l}>5 \text { medium } \\
\text { linear lesions }\end{array}$ & Mild inflammation & Absent & Absent & $\begin{array}{l}\text { Minimal thickening and } \\
\text { localised severe thickening }\end{array}$ & Absent & Moderate & $\begin{array}{l}\text { Fundus details } \\
\text { clearly visible }\end{array}$ \\
\hline 3 & $\begin{array}{l}>5 \text { large } \\
\text { linear lesions }\end{array}$ & $\begin{array}{l}\text { Moderate } \\
\text { inflammation }\end{array}$ & Absent & Absent & $\begin{array}{l}\text { Localised severe thickening } \\
\text { on all vessels or one vessel } \\
\text { grossly affected }\end{array}$ & Present & Severe & $\begin{array}{l}\text { Fundus details } \\
\text { visible }\end{array}$ \\
\hline 4 & $\begin{array}{l}\text { Confluent large } \\
\text { linear lesions }\end{array}$ & Severe inflammation & Present & Present & $\begin{array}{l}\text { One or all vessels } \\
\text { grossly affected }\end{array}$ & Present & Severe & $\begin{array}{l}\text { Fundus details } \\
\text { slightly unclear }\end{array}$ \\
\hline 5 & $\begin{array}{l}\text { Confluent large } \\
\text { linear lesions }\end{array}$ & Severe inflammation & Present & Present & $\begin{array}{l}\text { One or all vessels } \\
\text { grossly affected }\end{array}$ & Present & Severe & $\begin{array}{l}\text { Fundus details } \\
\text { not visible }\end{array}$ \\
\hline
\end{tabular}

brightfield ophthalmoscopy (Figure 1A), and revealed the distribution of the retinal microglia network in green fluorescent mode (Figure 1B) and normal retinal vasculature following fluorescein angiography (FA; Figure 1C). The time course of EAU was monitored in C57Bl/6 J $\mathrm{Cx}_{3} \mathrm{Cr} 1^{\mathrm{GFP} /+}$ mice immunized with IRBP $_{1-20}$ over four time points (d14, d21, d28, and d35 p.i.). EAU disease was first observed on d14 p.i. (Figure 1D-F), was maximal at d21 p.i. (Figure 1G-I) and d28 p.i. (Figure 1J-L), and was only slightly reduced in severity at d 35 p.i. (Figure 1M-O). All IRBP $1-20$ immunized mice developed EAU while adjuvant treated control mice appeared normal at all time points (Additional file 1: Figure S1A-C).

\section{Clinical examination of $\mathrm{C} 57 \mathrm{Bl} / 6 \mathrm{~J} \mathrm{CX}_{3} \mathrm{Cr} 1^{\mathrm{GFP} /+}$ mice during experimental autoimmune uveoretinitis reveals different disease severities}

EAU disease severity can vary in $\mathrm{IRBP}_{1-20}$ immunized $\mathrm{C} 57 \mathrm{Bl} / 6 \mathrm{~J} \mathrm{Cx} x_{3} \mathrm{Cr}^{\mathrm{GFP} /+}$ mice from mild (Additional file 1: Figure S1D-F), moderate (Additional file 1: Figure S1G-I) to severe (Additional file 1: Figure S1J-L) at all time points. Mild disease is characterized by swelling of the optic nerve head and mild vasculitis or perivenular cuffing (Additional file 1: Figure S1D), both evident due to accumulations of $\mathrm{Cx}_{3} \mathrm{Cr}$-GFP ${ }^{+}$myeloid cells (Additional file 1: Figure S1E). However, no fluorescein leakage was noted in FA at this point although only the early filling phase was examined (Additional file 1: Figure S1F). Moderate grades are characterised by multiple small focal retinal lesions with moderate vasculitis affecting all retinal vessels evident in brightfield (Additional file 1: Figure S1G) and as $\mathrm{Cx}_{3} \mathrm{Cr}$ - $\mathrm{GFP}^{+}$perivenular infiltrates (Additional file 1: Figure $\mathrm{S} 1 \mathrm{H}$ ) with an absence of fluorescein leakage (Additional file 1: Figure S1I). Despite the presence of $\mathrm{Cx}_{3} \mathrm{Cr}-\mathrm{GFP}^{+}$perivenular infiltrates, $\mathrm{Cx}_{3} \mathrm{Cr} 1-\mathrm{GFP}^{+}$cellular infiltrates were absent in some focal retinal lesions seen in brightfield (Additional file 1: Figure S1G). Severe EAU can occasionally be detected as early as d14 p.i. and in the eyes where EAU disease was seen to be severe, multiple large retinal lesions and vasculitis affecting all retinal veins was noted (Additional file 1: Figure S1J). Marked $\mathrm{Cx}_{3} \mathrm{Cr} 1-$ $\mathrm{GPF}^{+}$peri-vascular infiltrates (Additional file 1: Figure S1K) sometimes correlated with leakage of fluorescein (Additional file 1: Figure S1L). The short 5 second brightfield fundus video also demonstrated rolling and migration of $\mathrm{Cx}_{3} \mathrm{Cr} 1-\mathrm{GFP}^{+}$cells and non-Cx $\mathrm{Cx}_{3} \mathrm{Cr} 1-\mathrm{GFP}^{+}$ cells in the retinal veins (Additional file 2: Supplementary video 1 ).

To eliminate the possibility that the hyperfluorescent

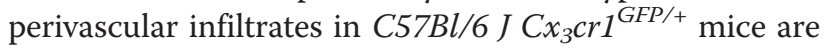
due to autofluorescence inflammatory cells we have provided clinical fundus images of $\mathrm{IRBP}_{1-20}$ immunized Wildtype C57Bl/6 J taken at $\mathrm{d} 21$ p.i. (Additional file 3: Figure S2).

Clinical grading strongly correlates with histopathological grade of experimental autoimmune uveoretinitis disease in $\mathrm{C} 57 \mathrm{BI} / 6 \mathrm{~J} \mathrm{CX}_{3} \mathrm{Cr} 1^{\mathrm{GFP} / \mathrm{+}}$ mice at day 35 post-immunization EAU clinical disease scores from all clinical imaging time points were determined by two masked observers using the grading criteria (Table 2). All adjuvant controls appeared normal at all time points (Figure 2A) and no histopathological changes were observed at d35 p.i. (Figure 2C). In IRBP $_{1-20}$ immunized C57Bl/6 $\mathrm{J} \mathrm{Cx} x_{3} \mathrm{Cr} 1^{\text {GFP/+ }}$ mice EAU began to develop around d14 p.i. with grade $1.86 \pm 0.33$ (mean \pm SEM) disease then gradually progressed over time and remained at grade $2.81 \pm 0.24$ until d 35 p.i. (Figure $2 \mathrm{~A}$ ).

Histopathological disease scores in $\mathrm{C} 57 \mathrm{Bl} / 6 \mathrm{~J} \mathrm{Cx_{3 } \mathrm { Cr } 1 ^ { \mathrm { GFP } / + }}$ mice at $\mathrm{d} 35$ p.i. revealed a mean infiltrative grade of $2.38 \pm 0.60$ and a structural grade of $2.00 \pm 0.38$. Total histopathological score shows a significant positive correlation $(\mathrm{r}=0.73 ; P=0.019)$ with the clinical scores (Figure 2B). C57Bl/6 $\mathrm{J} \mathrm{Cx} x_{3} \mathrm{Cr}^{\mathrm{GFP} /+}$ mice immunized with $\mathrm{IRBP}_{1-20}$ displayed classical histopathological features of EAU (Figure 2D-F), which have been described previously by several authors [6,28-30]. 


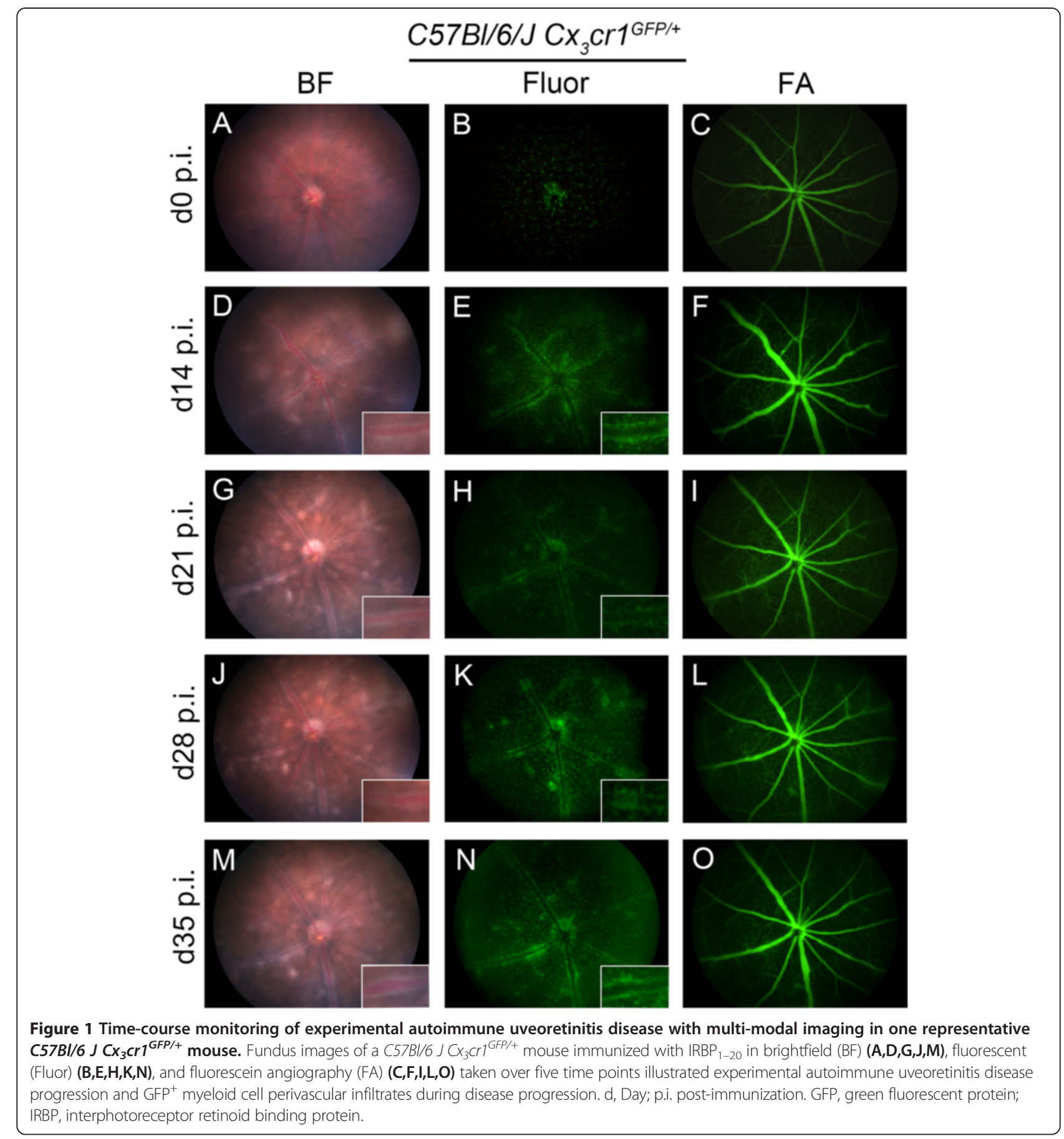

C57BI/6/J $\mathrm{Cx}_{3} \mathrm{Cr}^{\mathrm{GFP} /+}$

Clinical examination of experimental autoimmune uveoretinitis in C57BI/6 N CD11C-eYFP mice

The C57Bl/6 N CD11c-eYFP mouse has been extensively used to map putative DCs in a variety of tissues [25,31-36]. We have recently described our discovery of the presence of the $r d 8$ mutation in the $\mathrm{Crb1}$ gene in the $\mathrm{C} 57 \mathrm{Bl} / 6 \mathrm{~N}$ CD11c-eYFP mice [22]. Multiple retinal lesions (Figure 3A) were observed in the fundus of naïve $\mathrm{C} 57 \mathrm{Bl} / 6 \mathrm{~N} \mathrm{CD11c}$ eYFP mice and we illustrated that these lesions co-localized with CD11c-eYFP ${ }^{+}$cells (Figure 3B) [22]. At the time of our experiments to investigate the course of $E A U$ in C57Bl/6 N CD11c-eYFP mice we were unaware of the $r d 8$ mutation. It was during clinical examination of $\mathrm{d} 0$ naïve animals that we became suspicious of a baseline pathological status. Despite the presence of retinal degeneration, EAU was readily induced and typical EAU changes were noted in C57Bl/6 N CD11c-eYFP mice on d14 and d21 p.i. By d14 p.i. severe vasculitis was seen on brightfield 


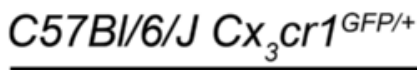

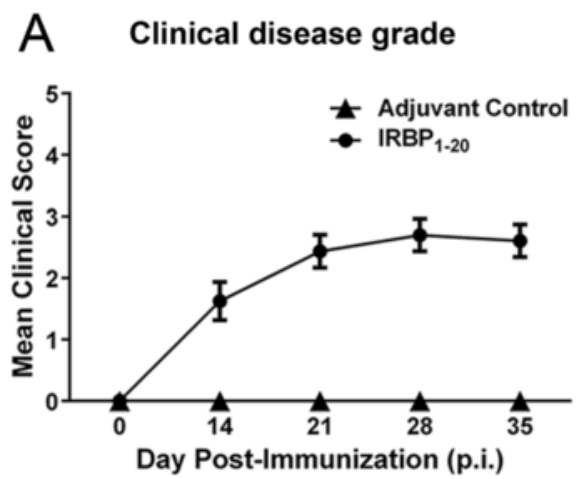

\section{B Correlation between clinical and histopathological grade at d35 p.i.}
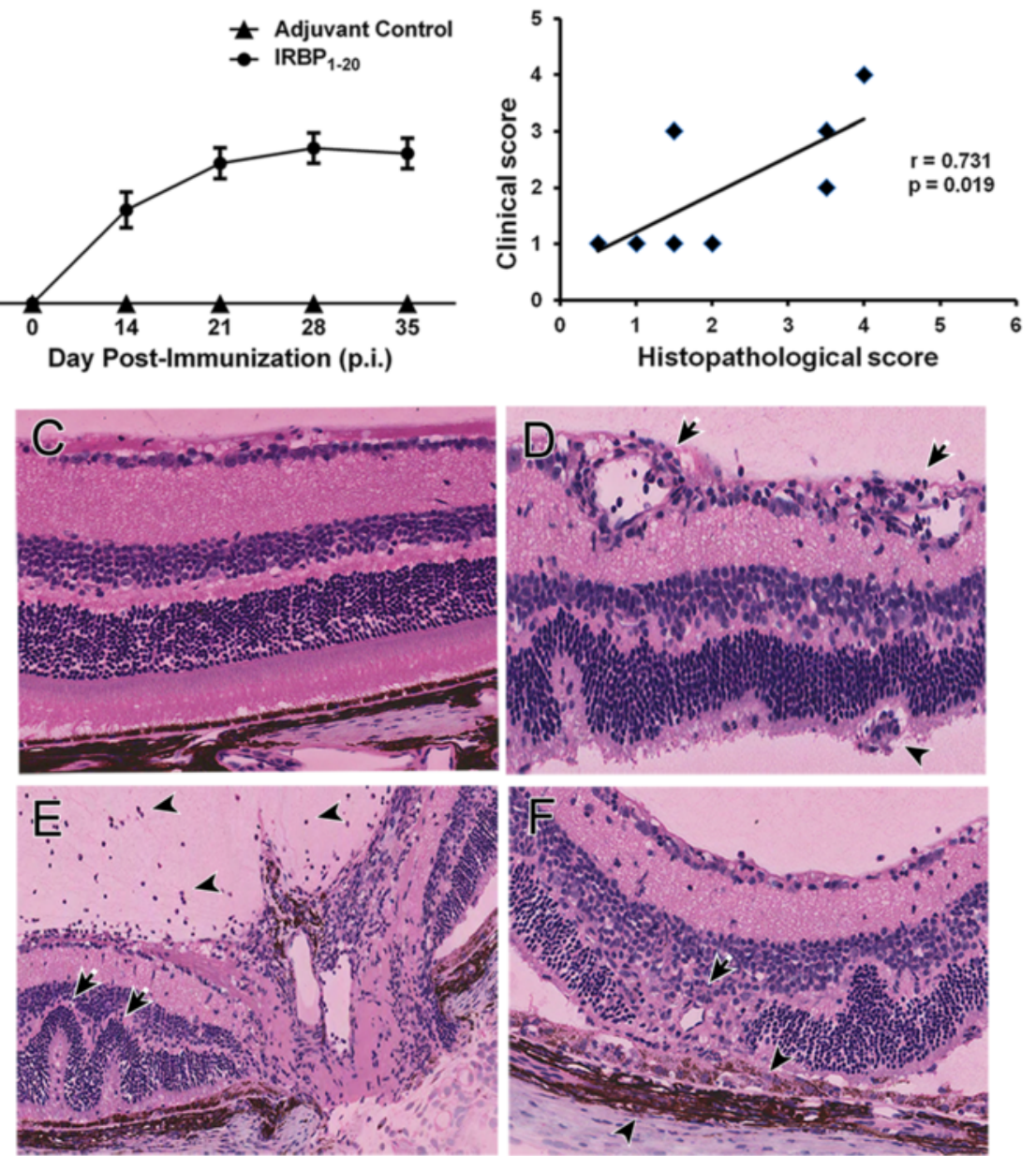

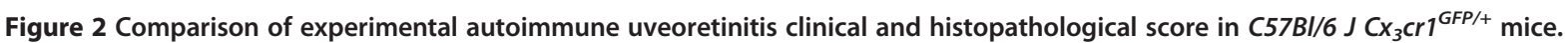
No adjuvant controls developed experimental autoimmune uveoretinitis (EAU). EAU clinical disease score (A) in C57B//6 J CX $3 \mathrm{Cr}^{\mathrm{GFP} /+}$ mice revealed a grade 2.8 disease by day 35 (d35) post-immunization (p.i.) (adjuvant controls: d0, d14, and d28: $n=14$, d21 and 35: $n=24$; IRBP $1-20$ : d0: $n=33, d 14: n=24, d 21: n=32, d 28: n=20, d 35: n=28)$. (B) Correlation between total histopathological disease score in $C 57 B / / 6 \mathrm{~J} \mathrm{CX}{ }_{3} \mathrm{Cr} 1^{\mathrm{GFP} /+}$ mice on d35 p.i. and the clinical grade in the same mice $\left(\operatorname{IRBP}_{1-20}: \mathrm{n}=8\right)$. Pearson's correlation was applied to analyse the correlation and the correlation coefficient ( $r$ ) illustrate a strong positive linear correlation that is significant, $P<0.05$. (C) Histology demonstrated no pathology in adjuvant controls. Representative histology images from C57B//6 J $\mathrm{CX}_{3} \mathrm{Cr} 1^{\mathrm{GFP} /+}$ mice immunized with IRBP $1-20$ illustrate key histopathological features of EAU including vasculitis ( $\mathbf{D}$; arrows), granuloma (D; arrowhead), retinal folds (E; arrows), vitritis (E; arrowheads), loss of retinal outer nuclear layer and photoreceptor layer ( $\mathbf{F}$; arrow), and cellular infiltrates of the retinal pigment epithelium and choroid (F; arrowheads). IRBP, interphotoreceptor retinoid binding protein.

fundoscopy (Figure 3C) and a large influx of perivascular CD11c-eYFP ${ }^{+}$cells along retinal veins was observed in the fluorescent mode (Figure 3D) as well as in the brightfield due to the strong eYFP signal. Clinical examination on $\mathrm{d} 21$ p.i. revealed that vasculitis and the large influx of CD11c-eYFP ${ }^{+}$cells was partly resolved but multiple retinal lesions were still present, and CD11c$\mathrm{eYFP}^{+}$cells were more evenly distributed in the retina (Figure 3E,F). FA examination revealed absence of fluorescein leakage (data not shown). All $\mathrm{IRBP}_{1-20}$ immunized mice developed EAU while adjuvant treated control mice appeared normal at all time points.

Visualization of LysM-eGFP ${ }^{+}$myelomonocytic cell infiltration during experimental autoimmune uveoretinitis in C57BI/6 J LysM-eGFP mice

In $\mathrm{C} 57 \mathrm{Bl} / 6 \mathrm{~J}$ LysM-eGFP mice, eGFP is cloned into the LysM locus which is expressed in myelomonocytic cells (macrophages-eGFP ${ }^{\text {low }}$ and neutrophils-eGFP ${ }^{\text {high }}$ ) [26] and have been used for in vivo imaging of neutrophils in healthy 

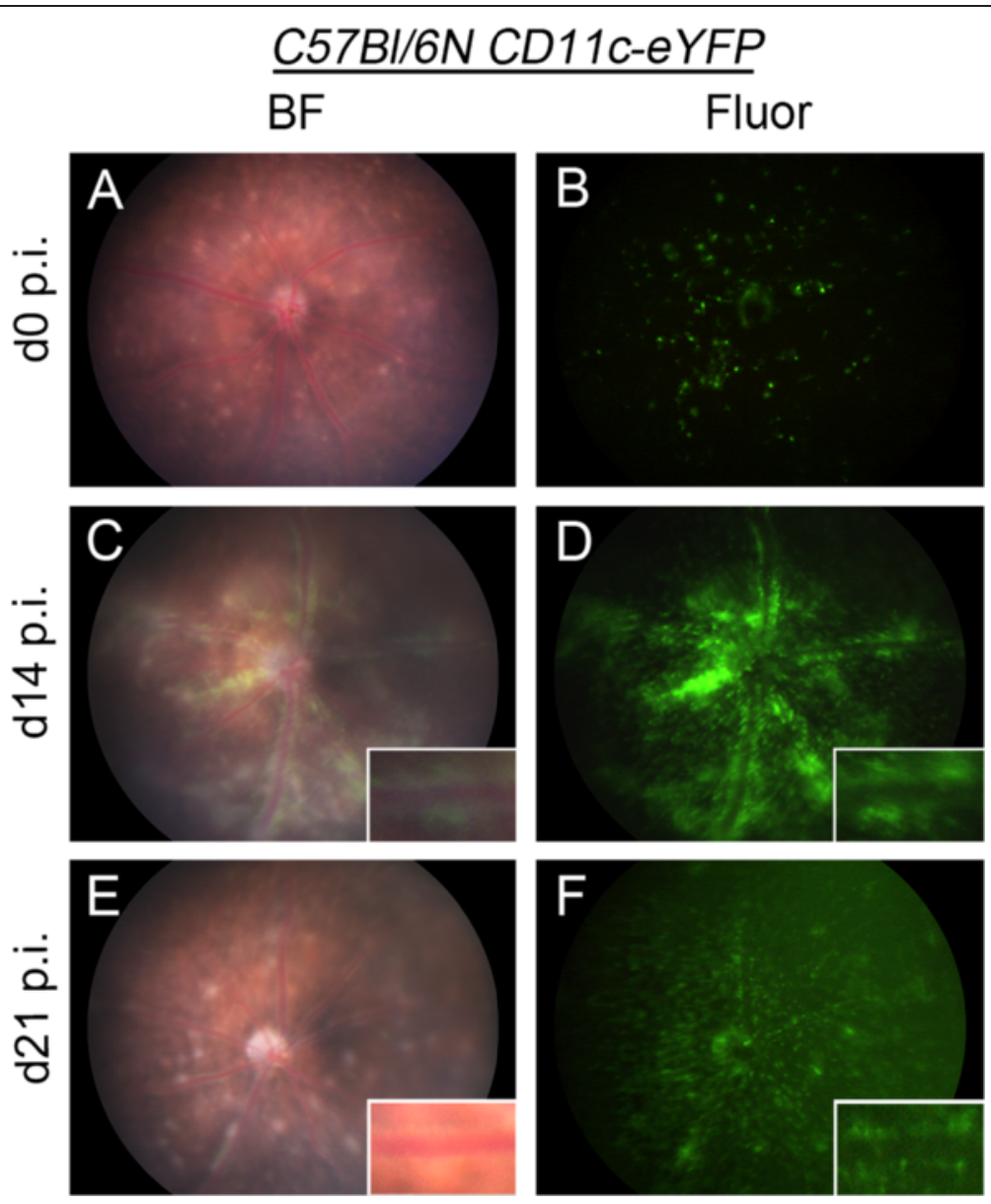

Figure 3 Clinical fundus examination of C57BI/6 N CD11C-eYFP mice in normal and diseased state. Fundus images of naïve C57B//6 N CD11c-eYFP (Crb1 ${ }^{\text {rd8 }}$ ) mice in brightfield (BF) (A) and fluorescent mode (Fluor) (B) displaying multiple retinal lesions and accumulation of CD11c-eYFP ${ }^{+}$cells in the retinal lesions attributable to the rd8 mutation. Fundus images of C57BI/6 N CD11c-eYFP mice $(n=10)$ immunized with $\mathrm{IRBP}_{1-20}$ on day 14 post-immunization (d14 p.i.) (C-D) and d21 p.i. (E-F) demonstrated perivascular infiltrates. eYFP, enhanced yellow fluorescent protein; rd8, retinal degeneration 8.

and diseased states [37]. In vivo imaging of the naïve C57Bl/6 J LysM-eGFP mouse fundus $(\mathrm{n}=5)$ revealed a normal appearance (Figure 4A) and genotyping of these mice demonstrated that they did not carry the $r d 8$ mutation (data not shown). In the naïve retina of these mice there were $16.6 \pm 1.18$ (mean \pm SEM) LysM-eGFP ${ }^{+}$cells present in the entire normal fundus (Figure 4B). However, upon examination of the clinical fundus video, transient LysM-eGFP ${ }^{+}$cells were observed travelling at high velocity through the lumina of the retinal vessels (Additional file 4: Supplementary video 2). In vivo imaging of $\operatorname{IRBP}_{1-20}$ immunized C57Bl/6 J LysM-eGFP mouse fundus on d14 p.i. illustrated mild EAU with swelling of the optic nerve head, mild vasculitis (Figure 4C) and accumulations of the LysM-eGFP ${ }^{+}$cells around the optic nerve head and along the retinal vessels (Figure 4D). Clinical fundus examination on $\mathrm{d} 21$ p.i. revealed multiple large retinal lesions and moderate vasculitis (Figure 4E) and the LysM-eGFP ${ }^{+}$cells were found along the retinal vessels and in retinal lesions
(Figure 4F). FA examination revealed absence of fluorescein leakage (data not shown). All IRBP ${ }_{1-20}$ immunized mice developed EAU while adjuvant treated control mice appeared normal at all time points.

\section{Discussion}

Intravital imaging using genetically modified reporter mice in which leukocyte subtypes are endogenously labelled with a fluorescent reporter gene transcript has greatly enhanced our understanding of cellular and immunological mechanisms during inflammation of several tissues [38-40]. Many of these experimental approaches are partly hindered or complicated by the potential effects of surgical intervention needed to exteriorise or surgically alter the tissue under investigation such as mesentery [41,42], cremaster muscle [42-44], liver [45], lung [37], kidney $[40,43]$, and skin [46]. In the case of intravital imaging of the brain a craniotomy window is required $[47,48]$. The eye has several advantages over most organs because by 


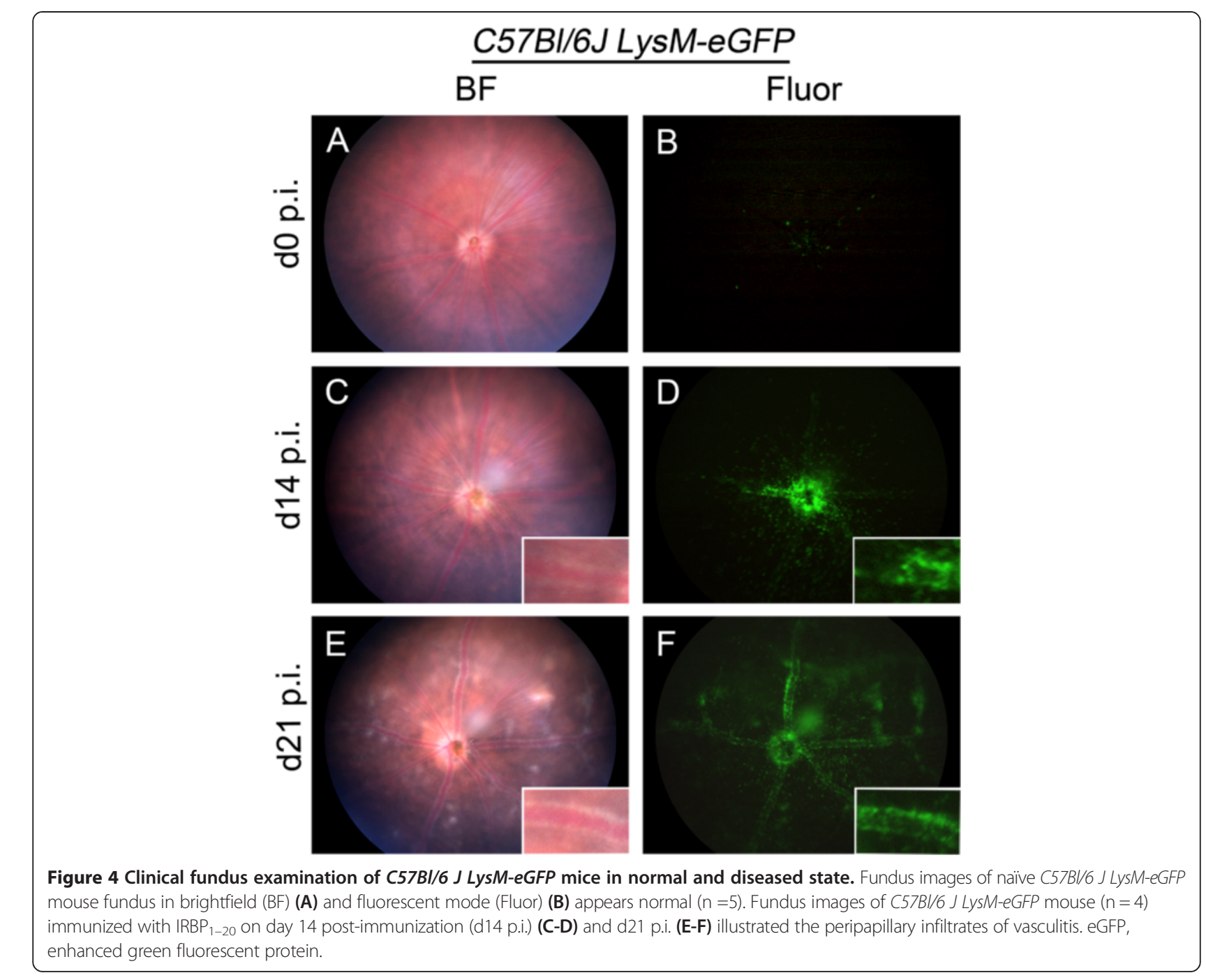

\section{ysM-eGFP}

its very nature it provides a clear transparent window on both neural tissue (retina) and connective tissues (cornea, iris) $[33,49]$, thus avoiding surgical intervention. We sought to exploit the recent development of multi-modal imaging techniques which allow high-quality examination of the mouse fundus $[16,22]$ to investigate the behaviour of cells of myeloid origin during the course of EAU, a widely used model of ocular autoimmune disease.

Disease severity of EAU is routinely determined using histopathological grading methods $[28,29,50]$. To circumvent the issue of single time point post-mortem grading, several research groups have developed non-invasive clinical grading methods including topical endoscopic fundus imaging [51], otoscope imaging [6], scanning laser ophthalmoscopy [52] and optical coherence tomography [53-55]. In this present study, multi-modal fundus ophthalmoscopy was chosen to grade the disease severity as it has the advantages of being relatively inexpensive and has the capability of capturing both video and still frame images in brightfield, together with green and red fluorescence wavelengths.

Many previous phenotypic analyses of the inflammatory cell infiltrate during EAU have used multi-parameter flow cytometry to show that the majority of infiltrating cells are myeloid-derived with a peak in $\mathrm{T}$ cell infiltration around d14 p.i. [11,56,57]. Alternative approaches to visualize leukocyte trafficking in vivo in the eye during EAU have included use of acridine orange, a non-specific nuclear dye which can be visualized by fluorography. This method revealed leukocytes rolling along the retinal veins as early as d14 p.i. [58,59]; however, their specific phenotype was obviously not determined. More recently, in vivo imaging of the leukocyte subtypes with more specificity has become easier with the availability of genetically modified mouse models in which genes regulating leukocyte subtypes are used as promoters to express fluorescent reporter proteins. Although these transgenic mouse models are useful for providing insights to myeloid lineage cell 
types in normal and diseased state, some authors have warned of cautious interpretation of these mice as the sole means of identifying and distinguishing macrophages and DCs [24]. Such limitations are also true of the three transgenic mouse lines chosen for the present study.

There are several subpopulations of $\mathrm{Cx}_{3} \mathrm{Cr} 1-\mathrm{GFP}^{+}$ myeloid-derived cells in the normal retina including the hyalocytes on the retinal surface [60], subretinal macrophages on the other aspect of the neural retinal [61-63], and the extensive network of microglial populations in the retinal parenchyma $[13,64]$. C57Bl/6 J $\mathrm{Cx}_{3} \mathrm{Cr} 1^{\mathrm{GFP} /+}$ mice [12] have been widely used to investigate the role of microglia in numerous ocular conditions that may have an inflammatory element in their pathogenesis including potential models of retinal degeneration [65], retinopathy of prematurity $[66,67]$ and diabetic retinopathy [16]. In the present study we demonstrate highly distinctive perivenular infiltrates of $\mathrm{Cx}_{3} \mathrm{Cr} 1-\mathrm{GFP}^{+}$cells at d14 p.i. to d35 p.i. which is in agreement with previous studies $[8,68]$. The perivenular infiltrate could theoretically represent haematogenous $\mathrm{Cx}_{3} \mathrm{Cr} 1-\mathrm{GPF}^{+}$(GFP ${ }^{\mathrm{low}}$ ) myeloid cells recently extravasated into the retina or the chemotactic migration of resident $\mathrm{Cx}_{3} \mathrm{Cr} 1-\mathrm{GPF}^{+}\left(\mathrm{GFP}^{\text {high }}\right)$ microglia towards the vasculature. We believe the former is the case as the $\mathrm{Cx}_{3} \mathrm{Cr} 1-\mathrm{GPF}^{+}\left(\mathrm{GFP}^{\text {high }}\right)$ microglia network seemed largely undisturbed, something that was subsequently confirmed by retinal whole mount analysis (data not shown).

The difficulty in distinguishing subpopulations of macrophages from cells of DC lineage was the motivation for the creation of CD11c transgenic reporter mice, specifically the CD11c-eYFP [25] and CD11c-DTR/GFP mice [69]. In these transgenic mice the promoter for the Itgax (CD11c) gene is used to drive eYFP expression (CD11c-eYFP mice) or GFP and diphtheria toxin receptor (DTR) expression (CD11c$D T R / G F P$ mice). CD11c is a leukocyte integrin comprised of an alpha $\mathrm{X}$ subunit that along with $\mathrm{CD} 18$, a leukocyte beta 2 integrin polypeptide, forms the CD11c/CD18 heterodimer which is important in leukocyte adhesion, migration and cell to cell interaction during immune responses. CD11c is expressed heterogeneously by different populations of DCs [25] and is important in T cell priming [69]. However, it is also expressed to at least one log lower than DCs on other immune cells such as natural killer cells, subpopulations of macrophages and activated $\mathrm{T}$ cells [25]. As such immune cells are not normally a feature of the resting central nervous system, we, like other previous investigators [31,32,70], thought is reasonably safe to assume that in the resting and disease state CD11c-eYFP ${ }^{+}$ cells may represent predominantly DCs. The view that CD11c-eYFP mice are valuable for examining the distribution of DCs has recently been strongly challenged by Hume [24] who points out that CD11c has no function in antigen presentation; not all $\mathrm{DCs}$ are $\mathrm{CD} 11 \mathrm{c}^{+}$and that not all $\mathrm{CD} 11 \mathrm{c}^{+}$cells are antigen-presenting cells. It was thus with caution that we chose to take advantage of the transgenic C57Bl/6 N CD11c-eYFP mice to examine the dynamic of DCs in EAU. Indeed at the commencement of this study we had the further complication of discovering that these mice had a pre-existing retinal dystrophy due to the presence of the $r d 8$ mutation in the $c r b 1$ gene [71] and that the CD11c-eYFP ${ }^{+}$cells in the retina represented activated microglia [22]. In the present study, CD11c-eYFP ${ }^{+}$ cells were recruited into the eye at $\mathrm{d} 14$ and $\mathrm{d} 21 \mathrm{p}$.i. in a similar pattern to that observed in $\mathrm{C} 57 \mathrm{Bl} / 6 \mathrm{~J} \mathrm{Cx_{3 }} \mathrm{Cr}^{\mathrm{GFP} /+}$ mice leading us to conclude that these CD11c-eYFP ${ }^{+}$cells are likely a mixture of myeloid-derived cells.

Interestingly, despite the $C 57 B l / 6 N C D 11 c-e Y F P$ mice carrying the $r d 8$ mutation and the pre-existing disrupted retinal architecture prior to immunization, they did not develop a more severe form of EAU as may have been predicted if one were to assume that this dystrophic condition compromised the immune status of the retina as we have previously concluded [22], although we have not specifically proven that the blood-ocular barrier was compromised.

In the C57Bl/6 J LysM-eGFP mouse line generated by Faust and colleagues [26], homologous recombination was used to insert the eGFP gene into the LysM locus. This was chosen because LysM is expressed specifically in the myelomonocytic cell lineage (macrophages and neutrophil granulocytes). Characterization of LysM-eGFP ${ }^{+}$cells in the blood revealed that the eGFP ${ }^{\text {high }}$ polymorphonuclear granulocytes outnumbered LysM-eGFP ${ }^{+}$monocytes by 50:1. In the present study, we observed exceedingly small numbers $(16.6 \pm 1.18)$ of largely static LysM-eGFP ${ }^{+}$myelomonocytic cells around the optic nerve head in the normal C57Bl/6 J LysM-eGFP fundus. We propose that these are likely of monocyte lineage as it is highly unusual to detect extravasated neutophils in the normal retina. However, video analysis (not shown) revealed many LysM-eGFP ${ }^{+}$ travelling at high velocity in retinal vessel lumina, which we conclude are likely to be circulating neutrophils. In these mice we demonstrated increased numbers of LysM-eGFP ${ }^{+}$cells in the peripapillary retinal vessels at d14 to d21 of EAU. Closer examination of the high power images (see inset, Figure 4) suggests that many of these are marginating in vessel lumina, a pattern which differs from the perivascular infiltrates observed in the C57Bl/6 J Cx $x_{3} \mathrm{Cr}^{\mathrm{GFP} /+}$ and C57Bl/6 N CD11c-eYFP mice. Subsequent flow cytometry of retinal tissue during EAU in C57Bl/6 J LysM-eGFP mice revealed these cells to be largely a neutrophilic infiltrate (Goldberg and colleagues, unpublished data).

\section{Conclusions}

In conclusion, in vivo fundus imaging of $C 57 \mathrm{Bl} / 6 \mathrm{~J}$ $\mathrm{Cx}_{3} \mathrm{Cr}^{\mathrm{GFP} /+}$ and $\mathrm{C} 57 \mathrm{Bl} / 6 \mathrm{~N} \mathrm{CD11c-eYFP}$ mice revealed 
the dynamics of the myeloid cell infiltrates in EAU, particularly the perivenular accumulations. In contrast, the C57Bl/6 J LysM-eGFP mice revealed intravascular margination of LysM-eGFP ${ }^{\text {hi }}$ neutrophils as well as less distinctive perivascular infiltrates. The grading of disease using in vivo imaging of these genetically modified reporter mice correlated strongly with the histopathological changes.

\section{Additional files}

Additional file 1: Figure S1. Clinical appearance of $C 57 \mathrm{~B} / / 6 \mathrm{~J} \mathrm{CX}_{3} \mathrm{Cr} 7^{\mathrm{GFP} / \mathrm{f}}$ mouse fundus with different severities of EAU. Fundus images of adjuvant control C57B//6 J $\mathrm{CX}_{3} \mathrm{Cr} 7^{\mathrm{GPP} / \mathrm{t}}$ mouse in brightfield (A), fluorescent mode (B), and fluorescein angiography $(C)$ revealed normal retinal vasculature with no fluorescein leakage and normal retinal microglia network. Multi-modal fundus images from $\left.\mathrm{C} 57 \mathrm{~B} / / 6 \mathrm{~J} \mathrm{CX}_{3} \mathrm{Cr}\right]^{\mathrm{GFP} /+}$ mice immunized with $\mathrm{IRBP}_{1-20}$ displaying mild (D-F), moderate EAU (G-I), and severe (J-L) EAU. The classical features of EAU include perivascular vasculitis ( $D$ and $J$, arrows) that is associated with GFP ${ }^{+}$perivascular infiltrates (E and K, arrows) and multiple focal retinal lesions ( $G$, arrows), venular dilation ( $L$, arrows), and fluorescein leakage $(L$, arrowhead).

Additional file 2: Supplementary Video 1. Video of real time in vivo visualization of rolling leukocytes in retinal veins of C57B//6 J C $x_{3} C r 7^{G F P /+}$ mouse during EAU. Duration: 5 seconds (20 frames per second).

Additional file 3: Figure S2. Clinical appearance of immunized with $\mathrm{IRBP}_{1-20}$ WT C57B//6 J mouse fundus on d21 p.i. These fundus images of WT controls in brightfield (A), fluorescent mode (B), and fluorescein angiography (C) revealed that the inflammatory infiltrated did not autofluoresce.

Additional file 4: Supplementary Video 2. Video of real time in vivo visualization of naïve C57B//6 J LysM-eGFP mouse fundus revealed static and circulating LysM-eGFP+ myelomonocytic cells. Duration: 5 seconds (20 frames per second).

\section{Abbreviations}

CFA: complete Freund's adjuvant; Crb1: crumbs 1; d: day; DC: dendritic cell; DTR: diphtheria toxin receptor; EAU: experimental autoimmune uveoretinitis; eGFP: enhanced green fluorescent protein; eYFP: enhanced yellow fluorescent protein; FA: fluorescein angiography; i.p.: intraperitoneal; IRBP: interphotoreceptor retinoid binding protein; LysM: lysozyme M; PBS: phosphate-buffered saline; PCR: polymerase chain reaction; PFA: paraformaldehyde; pi.: post-immunization; rd8: retinal degeneration 8; s.c.: subcutaneous.

\section{Competing interests}

The authors declare that they have no competing interests.

\section{Authors' contributions}

$X C$ performed the immunization, in vivo analysis, tissue collection and subsequent histology, and drafted the manuscript. JMK was part supervisor of XC during her PhD studies and helped plan the study. JVF and CCB were also part supervisors of XC and advised on the experimental approach and reviewed the manuscript. GLG and IPW provided data from the C57BI/6 J LysM-eGFP mice. PGM is the principle chief investigator in whose laboratory the studies were performed, and was primarily responsible with XC for the clinical grading, data analysis, data interpretation and writing of the manuscript. All authors read and approved the final manuscript.

\section{Acknowledgements}

The authors would like to acknowledge Ms Katherine Lim and Dr Jimmy Leong (Monash University, Clayton, VIC, Australia) for masking the clinical fundus images and histological slides for disease grading, and Ms Manpreet Sidhu (Monash University) for assisting with the fundus imaging. The C57B//6 CD11C-eYFP and C57B//6 J LysM-eGFP mice were kindly provided by Associate Professor Michael Hickey. XC is a recipient of National Health and Medical Research Council (NH\&MRC) Dora Lush Biomedical postgraduate scholarship (1039575). GLG is a recipient of the NH\&MRC Career Development Fellowship (1034598). CCB is supported by grants from the NH\&MRC (1053621), the Victoria/CIRM Joint Project (RMI-01739) and the Department of Industry (AISRF06680), Commonwealth of Australia. PGMcM receives support from the NH\&MRC (1069979).

\section{Author details}

'Department of Anatomy and Developmental Biology, School of Biomedical Sciences, Faculty of Medicine, Nursing and Health Sciences, Monash University, Clayton, Victoria, Australia. ${ }^{2}$ Section of Immunology and Infection, Division of Applied Medicine, School of Medicine and Dentistry, Institute of Medical Science, Foresterhill, University of Aberdeen, Scotland, UK. ${ }^{3}$ Ocular Immunology Program, Centre for Ophthalmology and Visual Science, The University of Western Australia, Crawley, Western Australia, Australia. ${ }^{4}$ Centre for Experimental Immunology, Lions Eye Institute, Nedlands, Crawley, Western Australia, Australia. ${ }^{5}$ Walter and Eliza Hall Institute of Medical Research, Parkville, Victoria, Australia. ${ }^{6}$ Australian Regenerative Medicine Institute, Monash University, Clayton, Victoria, Australia.

Received: 29 October 2014 Accepted: 5 January 2015

Published online: 27 January 2015

\section{References}

1. Durrani OM, Meads CA, Murray PI. Uveitis: a potentially blinding disease. Ophthalmologica. 2004;218:223-36.

2. Suttorp-Schulten MS, Rothova A. The possible impact of uveitis in blindness: a literature survey. Br J Ophthalmol. 1996;80:844-8.

3. Rothova A, Suttorp-van Schulten MS, Frits Treffers W, Kijlstra A. Causes and frequency of blindness in patients with intraocular inflammatory disease. Br J Ophthalmol. 1996;80:332-6.

4. Caspi RR. A look at autoimmunity and inflammation in the eye. J Clin Invest. 2010;120:3073-83.

5. Forrester JV. Endogenous posterior uveitis. Br J Ophthalmol. 1990;74:620-3.

6. Xu H, Koch P, Chen M, Lau A, Reid DM, Forrester JV. A clinical grading system for retinal inflammation in the chronic model of experimental autoimmune uveoretinitis using digital fundus images. Exp Eye Res. 2008;87:319-26.

7. Rao NA, Kimoto T, Zamir E, Giri R, Wang R, Ito $S$, et al. Pathogenic role of retinal microglia in experimental uveoretinitis. Invest Ophthalmol Vis Sci. 2003;44:22-31.

8. Kezic J, McMenamin PG. The monocyte chemokine receptor CX3CR1 does not play a significant role in the pathogenesis of experimental autoimmune uveoretinitis. Invest Ophthalmol Vis Sci. 2010;51:5121-7.

9. Chan C-C, Li Q. Immunopathology of uveitis. Br J Ophthalmol. 1998;82:91-6.

10. Jiang $H-R$, Lumsden L, Forrester JV. Macrophages and dendritic cells in IRBP-induced experimental autoimmune uveoretinitis in B10RIII mice. Invest Ophthalmol Vis Sci. 1999;40:3177-85.

11. Kerr EC, Raveney BJE, Copland DA, Dick AD, Nicholson LB. Analysis of retinal cellular infiltrate in experimental autoimmune uveoretinitis reveals multiple regulatory cell populations. J Autoimmun. 2008;31:354-61.

12. Jung S, Aliberti J, Graemmel P, Sunshine MJ, Kreutzberg GW, Sher A, et al. Analysis of fractalkine receptor CX3CR1 function by targeted deletion and green fluorescent protein reporter gene insertion. Mol Cell Biol. 2000;20:4106-14.

13. Langmann T. Microglia activation in retinal degeneration. J Leukoc Biol. 2007;81:1345-51

14. Lee JE, Liang KJ, Fariss RN, Wong WT. Ex vivo dynamic imaging of retinal microglia using time-lapse confocal microscopy. Invest Ophthalmol Vis Sci. 2008;49:4169-76

15. Liang KJ, Lee JE, Wang YD, Ma W, Fontainhas AM, Fariss RN, et al. Regulation of dynamic behavior of retinal microglia by CX3CR1 signaling. Invest Ophthalmol Vis Sci. 2009;50:4444-51.

16. Kezic JM, Chen X, Rakoczy EP, McMenamin PG. The effects of age and Cx3cr1 deficiency on retinal microglia in the Ins2Akita diabetic mouse. Invest Ophthalmol Vis Sci. 2013;54:854-63.

17. Karlstetter M, Ebert S, Langmann T. Microglia in the healthy and degenerating retina: insights from novel mouse models. Immunobiology. 2010;215:685-91.

18. Liu Z, Condello C, Schain A, Harb R, Grutzendler J. CX3CR1 in microglia regulates brain amyloid deposition through selective protofibrillar amyloid- $\beta$ phagocytosis. J Neurosci. 2010;30:17091-101.

19. Michaud J-P, Bellavance M-A, Préfontaine P, Rivest S. Real-time in vivo imaging reveals the ability of monocytes to clear vascular amyloid beta. Cell Reports. 2013;5:646-53.

20. Nimmerjahn A, Kirchhoff F, Helmchen F. Resting microglial cells are highly dynamic surveillants of brain parenchyma in vivo. Science. 2005;308:1314-8. 
21. Alt C, Runnels JM, Teo GSL, Lin PC. In vivo tracking of hematopoietic cells in the retina of chimeric mice with a scanning laser ophthalmoscope. IntraVital. 2012;1:132-40.

22. Chen X, Kezic J, Bernard C, McMenamin PG. Rd8 mutation in the Crb1 gene of CD11c-eYFP transgenic reporter mice results in abnormal numbers of CD11c-positive cells in the retina. J Neuropathol Exp Neurol. 2013;72:782-90.

23. Spencer D, Lee E, Kawaguchi T, Rosenbaum J. In vivo imaging of the immune response in the eye. Semin Immunopathol. 2008;30:179-90.

24. Hume DA. Applications of myeloid-specific promoters in transgenic mice support in vivo imaging and functional genomics but do not support the concept of distinct macrophage and dendritic cell lineages or roles in immunity. J Leukoc Biol. 2011;89:525-38.

25. Lindquist RL, Shakhar G, Dudziak D, Wardemann H, Eisenreich T, Dustin ML, et al. Visualizing dendritic cell networks in vivo. Nat Immunol. 2004;5:1243-50.

26. Faust N, Varas F, Kelly LM, Heck S, Graf T. Insertion of enhanced green fluorescent protein into the lysozyme gene creates mice with green fluorescent granulocytes and macrophages. Blood. 2000;96:719-26.

27. Abramoff MD, Magelhaes PJ, Ram SJ. Image processing with ImageJ. Biophotonics Int. 2004;11:36-42.

28. Dick AD, Cheng YF, Liversidge J, Forrester JV. Immunomodulation of experimental autoimmune uveoretinitis: a model of tolerance induction with retinal antigens. Eye. 1994:8:52-9.

29. Chan C-C, Caspi RR, Ni M, Leake WC, Wiggert B, Chader GJ, et al. Pathology of experimental autoimmune uveoretinitis in mice. J Autoimmun. 1990;3:247-55.

30. Cortes LM, Mattapallil MJ, Silver PB, Donoso LA, Liou Gl, Zhu W, et al. Repertoire analysis and new pathogenic epitopes of IRBP in C57BL/6 ( $\mathrm{H}-2 \mathrm{~b})$ and B10.RIII (H-2r) mice. Invest Ophthalmol Vis Sci. 2008;49:1946-56.

31. Anandasabapathy N, Victora GD, Meredith M, Feder R, Dong B, Kluger C, et al. Flt3L controls the development of radiosensitive dendritic cells in the meninges and choroid plexus of the steady-state mouse brain. J Exp Med. 2011;208:1695-705.

32. Kaunzner UW, Miller MM, Gottfried-Blackmore A, Gal-Toth J, Felger JC, McEwen BS, et al. Accumulation of resident and peripheral dendritic cells in the aging CNS. Neurobiol Aging. 2012;33:681-93. e681.

33. Lee EJ, Rosenbaum JT, Planck SR. Epifluorescence intravital microscopy of murine corneal dendritic cells. Invest Ophthalmol Vis Sci. 2010;51:2101-8.

34. Gelman AE, Li W, Richardson SB, Zinselmeyer BH, Lai J, Okazaki M, et al. Cutting edge: acute lung allograft rejection is independent of secondary lymphoid organs. J Immunol. 2009;182:3969-73.

35. Ng LG, Hsu A, Mandell MA, Roediger B, Hoeller C, Mrass P, et al. Migratory dermal dendritic cells act as rapid sensors of protozoan parasites. PLoS Pathog. 2008:4:e1000222

36. McDole JR, Wheeler LW, McDonald KG, Wang B, Konjufca V, Knoop KA, et al. Goblet cells deliver luminal antigen to CD103+ dendritic cells in the small intestine. Nature. 2012:483:345-9.

37. Kreisel D, Nava RG, Li W, Zinselmeyer BH, Wang B, Lai J, et al. In vivo two-photon imaging reveals monocyte-dependent neutrophil extravasation during pulmonary inflammation. Proc Natl Acad Sci U S A. 2010;107:18073-8.

38. Germain RN, Miller MJ, Dustin ML, Nussenzweig MC. Dynamic imaging of the immune system: progress, pitfalls and promise. Nat Rev Immunol. 2006;6:497-507.

39. Li JL, Goh CC, Keeble JL, Qin JS, Roediger B, Jain R, et al. Intravital multiphoton imaging of immune responses in the mouse ear skin. Nat Protocols. 2012;7:221-34.

40. Small DM, Sanchez WY, Roy S, Hickey MJ, Gobe GC. Multiphoton fluorescence microscopy of the live kidney in health and disease. J Biomed Opt. 2014;19:020901-1.

41. Grayson MH, Hotchkiss RS, Karl IE, Holtzman MJ, Chaplin DD. Intravital microscopy comparing $T$ lymphocyte trafficking to the spleen and the mesenteric lymph node. Am J Physiol Heart Circ Physiol. 2003;284:H2213-26.

42. Gavins FNE, Chatterjee BE. Intravital microscopy for the study of mouse microcirculation in anti-inflammatory drug research: focus on the mesentery and cremaster preparations. J Pharmacol Toxicol Methods. 2004;49:1-14.

43. Devi S, Li A, Westhorpe CLV, Lo CY, Abeynaike LD, Snelgrove SL, et al. Multiphoton imaging reveals a new leukocyte recruitment paradigm in the glomerulus. Nat Med. 2013;19:107-12.

44. Norman MU, Van De Velde NC, Timoshanko JR, Issekutz A, Hickey MJ. Overlapping roles of endothelial selectins and vascular cell adhesion molecule-1 in immune complex-induced leukocyte recruitment in the cremasteric microvasculature. Am J Pathol. 2003;163:1491-503.
45. Wong J, Johnston B, Lee SS, Bullard DC, Smith CW, Beaudet AL, et al. A minimal role for selectins in the recruitment of leukocytes into the inflamed liver microvasculature. J Clin Invest. 1997;99:2782-90.

46. Sorg $H$, Krueger C, Vollmar B. Intravital insights in skin wound healing using the mouse dorsal skin fold chamber. J Anat. 2007;211:810-8.

47. Pai S, Danne KJ, Qin J, Cavanagh LL, Smith A, Hickey MJ, et al. Visualising leukocyte trafficking in the living brain with 2-photon intravital microscopy. Front Cellular Neurosci. 2013;6(67):1-14.

48. Masedunskas A, Milberg O, Porat-Shliom N, Sramkova M, Wigand T, Amornphimoltham $P$, et al. Intravital microscopy: A practical guide on imaging intracellular structures in live animals. Bioarchitecture. 2012;2:143-57.

49. Camelo S, Shanley AC, Voon ASP, McMenamin PG. An intravital and confocal microscopic study of the distribution of intracameral antigen in the aqueous outflow pathways and limbus of the rat eye. Exp Eye Res. 2004;79:455-64

50. Caspi RR, Roberge FG, Chan CC, Wiggert B, Chader GJ, Rozenszajn LA, et al. A new model of autoimmune disease. Experimental autoimmune uveoretinitis induced in mice with two different retinal antigens. J Immunol. 1988;140:1490-5.

51. Copland DA, Wertheim MS, Armitage WJ, Nicholson LB, Raveney BJE, Dick AD. The clinical time-course of experimental autoimmune uveoretinitis using topical endoscopic fundal imaging with histologic and cellular infiltrate correlation. Invest Ophthalmol Vis Sci. 2008;49:5458-65.

52. Dagkalis A, Wallace C, Xu H, Liebau S, Manivannan A, Stone MA, et al. Development of experimental autoimmune uveitis: efficient recruitment of monocytes is independent of CCR2. Invest Ophthalmol Vis Sci. 2009;50:4288-94.

53. Chu CJ, Herrmann P, Carvalho LS, Liyanage SE, Bainbridge JWB, Ali RR, et al. Assessment and in vivo scoring of murine experimental autoimmune uveoretinitis using optical coherence tomography. PLoS ONE. 2013;8:e63002.

54. Gadjanski I, Williams SK, Hein K, Sättler MB, Bähr M, Diem R. Correlation of optical coherence tomography with clinical and histopathological findings in experimental autoimmune uveoretinitis. Exp Eye Res. 2011;93:82-90.

55. Chen J, Qian H, Horai R, Chan C-C, Caspi RR. Use of optical coherence tomography and electroretinography to evaluate retinal pathology in a mouse model of autoimmune uveitis. PLoS ONE. 2013;8:e63904.

56. Laliotou B, Dick AD. Modulating phenotype and cytokine production of leucocytic retinal infiltrate in experimental autoimmune uveoretinitis following intranasal tolerance induction with retinal antigens. $\mathrm{Br} J$ Ophthalmol. 1999:83:478-85.

57. Thurau SR, Mempel TR, Flügel A, Diedrichs-Möhring M, Krombach F, Kawakami $\mathrm{N}$, et al. The fate of autoreactive, GFP+ T cells in rat models of uveitis analyzed by intravital fluorescence microscopy and FACS. Int Immunol. 2004;16:1573-82.

58. Hamada M, Ogura Y, Miyamoto K, Nishiwaki H, Hiroshiba N, Honda Y. Retinal leukocyte behavior in experimental autoimmune uveoretinitis of rats. Exp Eye Res. 1997;65:445-50.

59. Parnaby-Price A, Stanford MR, Biggerstaff J, Howe L, Whiston RA, Marshall J, et al. Leukocyte trafficking in experimental autoimmune uveitis in vivo. J Leukoc Biol. 1998:64:434-40.

60. Vagaja NN, Chinnery HR, Binz N, Kezic JM, Rakoczy EP, McMenamin PG. Changes in murine hyalocytes are valuable early indicators of ocular disease. Invest Ophthalmol Vis Sci. 2012;53:1445-51.

61. Chinnery HR, McLenachan S, Humphries T, Kezic JM, Chen X, Ruitenberg MJ, et al. Accumulation of murine subretinal macrophages: effects of age, pigmentation and CX3CR1. Neurobiol Aging. 2011;33:1769-76.

62. Raoul W, Auvynet C, Camelo S, Guillonneau X, Feumi C, Combadiere C, et al. CCL2/CCR2 and CX3CL1/CX3CR1 chemokine axes and their possible involvement in age-related macular degeneration. J Neuroinflammation. 2010;7:87.

63. Luhmann UFO, Robbie S, Munro PMG, Barker SE, Duran Y, Luong V, et al. The Drusenlike phenotype in aging C $\mathrm{Cl} 2$-knockout mice is caused by an accelerated accumulation of swollen autofluorescent subretinal macrophages. Invest Ophthalmol Vis Sci. 2009;50:5934-43.

64. Dick AD. Influence of microglia on retinal progenitor cell turnover and cell replacement. Eye. 2008;23:1939-45.

65. Combadiere C, Feumi C, Raoul W, Keller N. Rod, Ro M, et al. CX3CR1-dependent subretinal microglia cell accumulation is associated with cardinal features of age-related macular degeneration. J Clin Invest. 2007;117:2920-8.

66. Zhao L, Ma W, Fariss RN, Wong WT. Retinal vascular repair and neovascularization are not dependent on CX3CR1 signaling in a model of ischemic retinopathy. Exp Eye Res. 2009:88:1004-13.

67. Fischer F, Martin G, Agostini H. Activation of retinal microglia rather than microglial cell density correlates with retinal neovascularization in the mouse model of oxygen-induced retinopathy. J Neuroinflammation. 2011;8:120. 
68. Dagkalis A, Wallace C, Hing B, Liversidge J, Crane IJ. CX3CR1-deficiency is associated with increased severity of disease in experimental autoimmune uveitis. Immunology. 2009;128:25-33.

69. Jung S, Unutmaz D, Wong P, Sano Gl, Delos Santos K, Sparwasser T, et al. In vivo depletion of CD11c + dendritic cells abrogates priming of CD8+ T cells by exogenous cell-associated antigens. Immunity. 2002;17:211-20.

70. Bulloch K, Miller MM, Gal-Toth J, Milner TA, Gottfried-Blackmore A, Waters EM, et al. CD11c/EYFP transgene illuminates a discrete network of dendritic cells within the embryonic, neonatal, adult, and injured mouse brain. $J$ Comp Neurol. 2008;508:687-710.

71. Mattapallil MJ, Wawrousek EF, Chan C-C, Zhao H, Roychoudhury J, Ferguson TA, et al. The Rd8 mutation of the Crb1 gene is present in vendor lines of C57BL/6 N mice and embryonic stem cells, and confounds ocular induced mutant phenotypes. Invest Ophthalmol Vis Sci. 2012;53:2921-7.

72. Medina-Contreras O, Geem D, Laur O, Williams IR, Lira SA, Nusrat A, et al. CX3CR1 regulates intestinal macrophage homeostasis, bacterial translocation, and colitogenic Th17 responses in mice. J Clin Invest. 2011;121:4787-95.

73. Kim K-W, Vallon-Eberhard A, Zigmond E, Farache J, Shezen E, Shakhar G, et al. In vivo structure/function and expression analysis of the CX3C chemokine fractalkine. Blood. 2011;118:e156-e167.

74. Hochheiser K, Heuser C, Krause TA, Teteris S, Ilias A, Weisheit C, et al. Exclusive CX3CR1 dependence of kidney DCs impacts glomerulonephritis progression. J Clin Invest. 2013;123:4242-54.

75. Lionakis MS, Swamydas M, Fischer BG, Plantinga TS, Johnson MD, Jaeger M, et al. CX3CR1-dependent renal macrophage survival promotes Candida control and host survival. J Clin Invest. 2013;123:5035-51.

76. Huang D, Shi F-D, Jung S, Pien GC, Wang J, Salazar-Mather TP, et al. The neuronal chemokine CX3CL1/fractalkine selectively recruits NK cells that modify experimental autoimmune encephalomyelitis within the central nervous system. FASEB J. 2006;20:896-905.

77. Ueno M, Fujita Y, Tanaka T, Nakamura Y, Kikuta J, Ishii M, et al. Layer V cortical neurons require microglial support for survival during postnatal development. Nat Neurosci. 2013;16:543-51.

78. Kezic J, Xu H, Chinnery HR, Murphy CC, McMenamin PG. Retinal microglia and uveal tract dendritic cells and macrophages are not CX3CR1 dependent in their recruitment and distribution in the young mouse eye. Invest Ophthalmol Vis Sci. 2008;49:1599-608.

79. Singh-Jasuja H, Thiolat A, Ribon M, Boissier M-C, Bessis N, Rammensee H-G, et al, The mouse dendritic cell marker CD11C is down-regulated upon cell activation through Toll-like receptor triggering. Immunobiology. 2013;218:28-39.

80. Felger JC, Abe T, Kaunzner UW, Gottfried-Blackmore A, Gal-Toth J, McEwen BS, et al. Brain dendritic cells in ischemic stroke: time course, activation state, and origin. Brain Behav Immun. 2010;24:724-37.

81. Lin A, Loughman JA, Zinselmeyer BH, Miller MJ, Caparon MG. Streptolysin S inhibits neutrophil recruitment during the early stages of streptococcus pyogenes infection. Infect Immun. 2009;77:5190-201.

82. Howe C, LaFrance-Corey R, Sundsbak R, LaFrance S. Inflammatory monocytes damage the hippocampus during acute picornavirus infection of the brain. J Neuroinflammation. 2012;9:50.

83. Byrne R, Rath E, Hladik A, Niederreiter B, Bonelli M, Frantal S, et al. A dynamic real time in vivo and static ex vivo analysis of granulomonocytic cell migration in the collagen-induced arthritis model. PLoS ONE. 2012;7:e35194.

\section{Submit your next manuscript to BioMed Central and take full advantage of:}

- Convenient online submission

- Thorough peer review

- No space constraints or color figure charges

- Immediate publication on acceptance

- Inclusion in PubMed, CAS, Scopus and Google Scholar

- Research which is freely available for redistribution 